\title{
Dezideráta szolgáltatás bevezetése az ELTE Egyetemi Könyvárban
}

\section{Szemléletváltás}

A dezideráta szolgáltatás bevezetése abban a formában új az Egyetemi Könyvtárban, ahogyan az előadásban elhangzott. Fejlesztés alatt álló szolgáltatásról van szó, melyet idén tervezünk bevezetni és a felhasználókkal is megismertetni. A szolgáltatás olvasók felé kommunikált nevére még nem született döntés, ennek véglegesítése folyamatban van.

A könyvtárban Szerzeményezési Bizottság müködik, melynek tagjai több osztály munkatársai közül kerülnek ki, biztosítva ezzel többféle szemlélet képviseletét mind olvasói, mind az állomány oldaláról nézve. A Szerzeményi Bizottság dönt az egyes dokumentumok esetén azok beszerzéséröl, arról, hogy hány példányban vegyük meg, és arról, hogy az melyik gyüjteményi helyre kerül.

Korábban is volt lehetősége az olvasóknak beszerzési kérést eljuttatni a könyvtár felé. Ennek leggyakoribb formái a szóbeli közlés, az e-mailben küldött, telefonon leadott, illetve a WebOPAC-on található, „Ha kérdése van, írjon!” rész kitöltésével küldött kérés voltak.

Az igények leginkább a Közönségszolgálati Osztályra érkeztek, kisebb részben a Gyüjteményszervező Osztályra. A kérések kezelését az eljárás lépéseinek, időtartamának és a küldött válaszoknak a különbözősége jellemezte.

Az új szolgáltatás bevezetése előtt megvizsgáltuk a dezideráta kérések leadásának hazai és a nemzetközi gyakorlatát. A skála viszonylag széles, a füzetbe írt kérésektől indulva a DDA (Demand Driven Acquisition = Kérés szerinti gyarapítás) szerinti gyarapításig. Ez utóbbi gyakorlat leginkább az USA-ban és Nyugat-Európában terjedt el. Az olvasók online keresőrendszerben választják ki a beszerzésre szánt dokumentumot, a DDA rekordot betöltik a könyvtár elektronikus katalógusába. A legtöbb könyvtár külön pénzalapot hoz létre a beérkezett kérések teljesítésére, melynek gyors megvalósulását a kiadókkal, kereskedőkkel és a szállítókkal kötött megállapodások, szerződések biztosítják.

A könyvtárunkban korábban leadott kéréseket - cél alapján vizsgálva - két csoportra oszthatjuk. Az egyik rész szerzeményezési javaslatot tett, melynek célja az állomány teljesebbé tétele volt, ekkor az olvasó nem kérte a példányhoz való hozzáférést. A javaslat leadásával felhívta a könyvtár figyelmét újonnan megjelent mủvekre, amelyek megvételével az adott szerző összes könyve meglehetne a könyvtárban, vagy esetleg jelezte, ha egy dokumentumból kevés példányszámmal rendelkezett a könyvtár. 
Másik esetben a leadott kérésnél a gyors beszerzés és a hozzáférés mihamarabbi biztosítása jelent meg igényként. Az ELTE helyi sajátságait figyelembe véve ez utóbbit jelentősen befolyásolta a rendelkezésre álló pénz és a bürokrácia. A közbeszerzési pályázatok hosszú átfutási ideje, az esetleges érvénytelen, majd az ezt követő újbóli pályázat, a költségvetés alakulása, az engedélyek aláírásának hosszú átfutási ideje nem kedvez a gyors beszerzésnek és feldolgozásnak. Ebben az esetben az ELTE hátrányba kerül azokkal a könyvtárakkal és szolgáltatókkal szemben, akik teljesíteni tudják a pár napon belüli hozzáférés követelményét.

A korábbi dezideráta kérés leadásnak eseteit, a hazai és nemzetközi gyakorlatokat, az ELTE sajátosságait megvizsgálva a könyvtár a szemléletváltás mellett döntött. Egyrészt az olvasóinkat hangsúlyozottan szeretnénk bevonni az állomány gyarapításának javaslat szinten történő támogatásába, másrészt a szemléletváltás a könyvtár és a könyvtáros részéről is megjelenik, hiszen eddig a gyarapítás könyvtárosi feladat volt, minimálisan jelent meg külső igény. Ennek alapján a korábbi szerzeményezési gyakorlat kiegészül az olvasói kérések megjelenésével.

Az új folyamat bevezetésének a fentiek mellett célja a folyamatszintủ müködés biztosítása, az egységes eljárás kialakítása, ezzel a párhuzamosságok kiszürése, a hatékonyság növelése, a minőségi szolgáltatás létrehozása és a statisztikák készítésének lehetősége.

\section{A fejlesztés első szakasza: a tervezés}

Elsőként megvizsgáltuk a dezideráta kérés hagyományos menetét, majd az abban rejlő kritikus, fejlesztendő pontokat azonosítva megfogalmaztuk az igényeket, és megvizsgáltuk a rendelkezésre álló erőforrásokat személyi, anyagi és eszköz oldalról is. Egyeztettünk az Aleph integrált könyvtári rendszer magyarországi forgalmazóival, az Ex-Lh Számítástechnikai Kft.-vel a lehetőségekről és a működésről, majd kiválasztottuk a végleges verziót. Ezt követően készítettük el a folyamatvázlatot az új szolgáltatásról.

A tervezéskor meghatároztuk, hogy a fejlesztésnek mind az angol, mind a magyar felületen párhuzamosan kell haladnia a webOPAC-on, és azt is, hogy minden lépést több böngészőből indulva is ellenőrizni kell, hogy a felhasználók megfelelö tartalmat és megjelenítést lássanak.

\section{A fejlesztés második szakasza: Aleph beállítások, levelezés}

Az Aleph módosítások során az első lépés az új gyüjtemény (Dezideráta) és az új példánystátus (Beszerzés alatt) kialakítása és paraméterezése volt. A webOPACon leadott kérések mindegyike a Dezideráta gyüjteménybe kerül, a példánystátusza „Beszerzés alatt” lesz.

Ezután következett a jogosultságok beállítása. Olvasói oldalról minden olvasói státusznak engedélyeztük a dezideráta kérés leadásának lehetőségét. Egy- 
ségesen adtuk meg a beküldhető kérések számát, amit lehetőség van csökkenteni vagy emelni együttesen vagy olvasói státuszonként is. Példánystátusz és gyüjtemény oldalról is engedélyeztük a kérést.

A kérés során létrejövő rekordba bekerül egy bázis kód, melynek funkciója az OAI-PMH (Open Archives Initiative Protocol for Metadata Harvesting) küldés tiltása és a listázási lehetőség biztosítása.

Az új folyamathoz kapcsolódóan központi e-mail címet hoztunk létre, melyen keresztül folyamatosan biztosítható a beérkezett kérések és a szolgáltatással kapcsolatos levelezés követése.

\section{A fejlesztés harmadik szakasza: webOPAC}

Ebben a szakaszban történt meg a dezideráta kérés ürlapjának kialakítása és a „Ha kérdése van, írjon!” rész módosítása a webOPAC-ban.

A „Ha kérdése van, írjon!” részen keresztül bejelentkezett olvasóként és vendégként is lehetőség van a könyvtáraknak üzenetet küldeni. Korábban itt is jeleztük a felhasználóknak, hogy a beszerzési kéréseiket elküldhetik a könyvtár felé. Ezt a részt a felvezető szövegből töröltük.

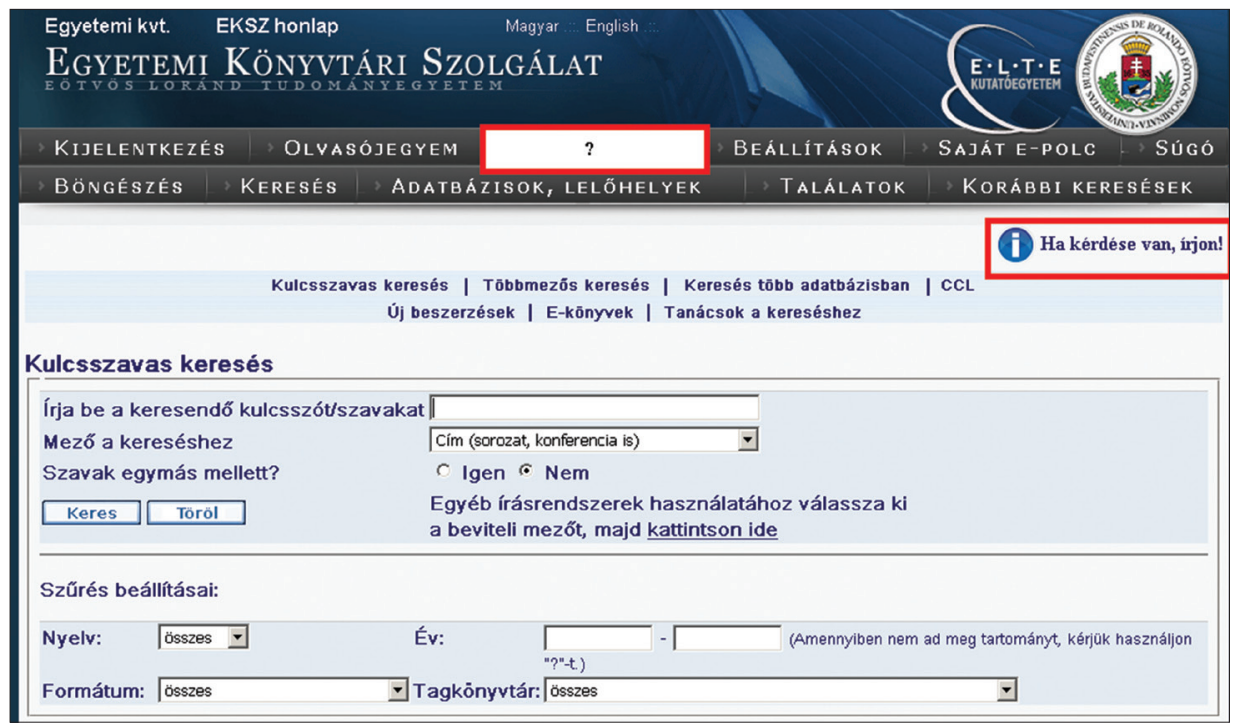

1. ábra. WebOPAC, dezideráta kérés helye és a Ha kérdése van, írjon! felület ${ }^{1}$

A webOPAC ürlap első részében tájékoztatjuk az olvasókat a szolgáltatásról, annak céljáról, menetéről, a visszajelzés formájáról.

${ }^{1}$ Forrás: http://opac.elte.hu/F/HI59CV5MIDSJHTTPSRBT2PTST41GQ9TEUSBJ3KBTLVUJ2SUB4I-31314? func=find-b-0 (2016. augusztus 31.) 
Mivel az Egyetemi Könyvtár teljes állománya nem kereshető a webOPACban, ezért az ürlap első részében kaptak helyet a digitalizált katalógusok linkjei. Megtalálhatók itt az alapkatalógus, a tárgyszókatalógus, az ETO katalógus és a Kézirat- és Ritkaságtár katalógusai. Ezen linkek bármelyikére kattintva az olvasónak lehetősége van ellenőrizni, hogy a beszerzésre javasolt dokumentum a könyvtár állományában megtalálható-e.

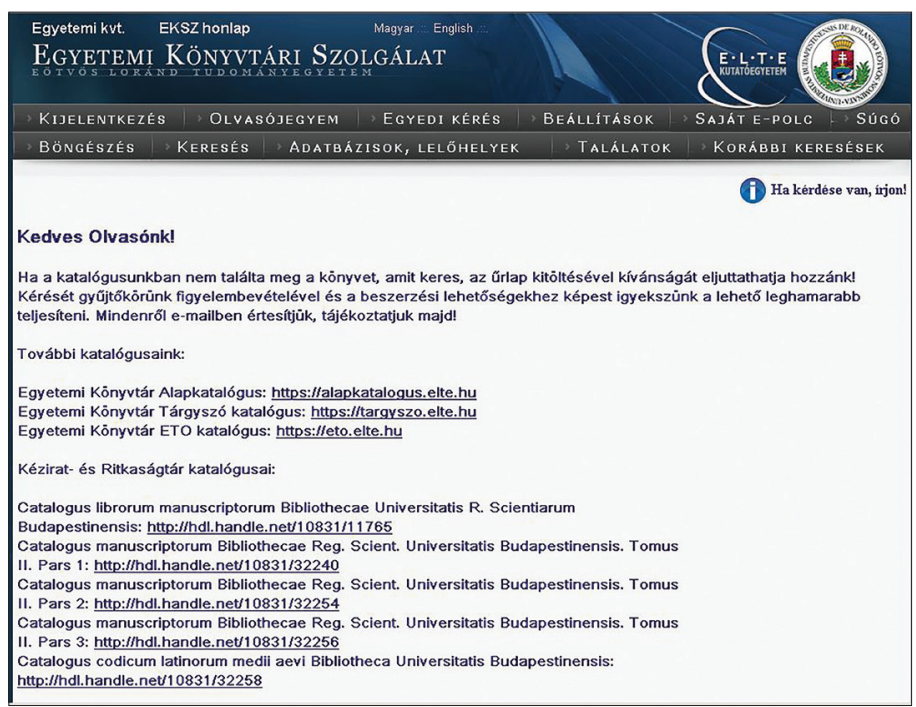

2. ábra. WebOPAC, a dezideráta kérés olvasói tájékoztatója²

A webOPAC ürlap második részében találhatók a kérésleadás kitöltendő mezői. Az ürlap kialakításakor arra törekedtünk, hogy a felület legyen átlátható, ne legyenek felesleges mezők, és olyan adatokat kérjünk a dokumentumról, amelyek egyértelmüsítik a kérést. A mezők közül a dokumentum címe és az olvasó e-mail címe kötelező mező. Ezek kitöltése nélkül a kérés nem indítható, az ürlap alján található „Rendben” gomb nem aktív.

A szerző és a kiadási év mező kitöltése nem kötelező, de segítséget nyújt a dokumentum azonosításához. Az ürlap végén található „Egyéb” nevü szabad szöveges mezőnél lehetőség van hosszabb megjegyzést füzni a kéréshez vagy akár linket beilleszteni, ami szintén segítheti a dokumentum egyértelmủ megtalálását. Itt írhatja meg az olvasó azt is, hogy milyen céllal kéri a dokumentum beszerzését.

Ha a kötelező mezők kitöltése megtörtént, akkor a „Rendben” gomb aktív lesz, ennek megnyomásával indítható a kérés. Beépítésre került egy captcha, melynek kitöltése után a kérés véglegesíthetö.

${ }^{2}$ Forrás: http://opac.elte.hu/F/HI59CV5MIDSJHTTPSRBT2PTST41GQ9TEUSBJ3KBTLVUJ2SUB4I-32033? func=new-record-0 (2016.augusztus 31.) 


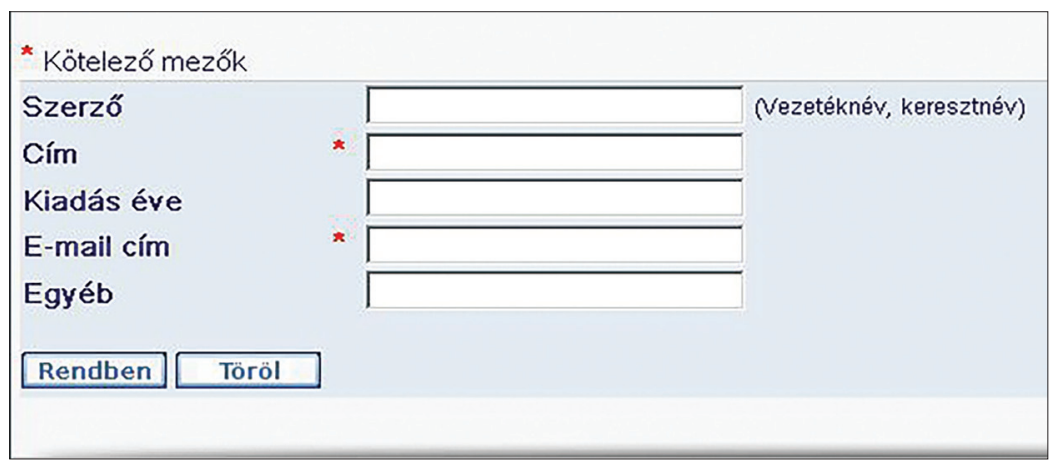

3. ábra. WebOPAC, a dezideráta kérés ürlapja ${ }^{3}$

A dezideráta kérés leadásához a felhasználónak be kell lépnie a webOPAC-ba. A most még deziderátának hívott gomb megnyomása után az ürlap kitöltése, a „Rendben” gomb megnyomása, a captcha kitöltése és a kérés véglegesítése következik. Ezzel létrejön egy rekord és példány az Aleph-ben, elöjegyzés kerül a példányra az olvasó nevével.

\section{Az olvasó tájékoztatása}

Az olvasó kap egy visszajelző e-mailt a kérésről, melyben tájékoztatjuk arról, hogy az üzenete megérkezett hozzánk, azt elbíráljuk és válaszolunk hamarosan, valamint a levél tartalmazza a kéréskor kitöltött mező adatait, így az olvasó láthatja, hogy mely kérésről van szó. Ugyanezt a levelet megkapja a könyvtár is. A könyvtáros feladata ellenőrizni, hogy a kért dokumentum a könyvtár állományában megtalálható-e. A lehetséges esetek:

a) A kért dokumentum megtalálható a webOPAC-ban az Egyetemi Könyvtár hozzáférhető vagy kölcsönzött példányaként.

b) A kért dokumentum megtalálható a webOPAC-ban egy másik ELTE-s tagkönyvtár hozzáférhető vagy kölcsönzött példányaként.

c) A kért dokumentum megtalálható valamely webOPAC-on kívüli katalógusban az Egyetemi Könyvtár példányaként.

d) A kért dokumentum nem található meg egyik katalógusban sem.

Az első két esetben az olvasót tájékoztatni kell a dokumentum meglétéről, a lelőhelyről, a hozzáférés módjáról, idejéről, illetve az előjegyzés lehetőségéről.

Előfordulhat, hogy a példány kötészeten van, esetleg külső raktárban. Az ezekhez kapcsolódó egyéb információkat (mikorra kötik be a dokumentumot, mikor van szállítás a külső raktárból) is el kell juttatni az olvasóhoz.

${ }^{3}$ Forrás: http://opac.elte.hu/F/HI59CV5MIDSJHTTPSRBT2PTST41GQ9TEUSBJ3KBTLVUJ2SUB4I-32033? func=new-record-0 (2016.augusztus 31.) 
A harmadik esetben az olvasó informálását megelőzi a dokumentum feldolgozása az integrált könyvtári rendszerben, és a gyüjteményi helyre irányítás.

A negyedik esetben a kérés a beszerzéssel foglalkozó könyvtárosokhoz kerül, akik elsősorban a belső Gyüjtőköri szabályzat és a rendelkezésre álló anyagi források figyelembevételével döntenek kiadvány megvételéröl.

Ahhoz, hogy az olvasó megkapja a szükséges információkat, szabványleveleket készítettünk, melyek a lehetséges esetekhez kapcsolódva adnak választ az olvasói kérésre. Ezek az alábbiak:

a) A kért dokumentum megvan az Egyetemi Könyvtárban, hozzáférhető.

b) A kért dokumentum megvan az Egyetemi Könyvtárban, de jelenleg nem hozzáférhető (más olvasó kölcsönözte, éppen előjegyezték, kötészeten vagy kiállításon van stb.).

c) A kért dokumentum megvan valamelyik ELTE-s tagkönyvtárban.

d) A kért dokumentum nincs meg az Egyetemi Könyvtárban, de a gyüjtőkörünkbe tartozik és beszerezzük.

e) A kért dokumentum nincs meg az Egyetemi Könyvtárban, nem tartozik a gyüjtőkörünkbe, s ezért nem szerezzük be.

f) A kért dokumentum nincs meg az Egyetemi Könyvtárban, jelenleg nincs forrás a beszerzésre, de amint lehetséges, beszerezzük.

g) A kért dokumentum nincs meg az Egyetemi Könyvtárban, jelenleg nem lehet beszerezni, ha kapható lesz, beszerezzük.

h) A kért dokumentum nincs meg az Egyetemi Könyvtárban, nem gyüjtőkörünk, de továbbítottuk a kérést annak az ELTE-s tag könyvtárnak, amelyhez témája alapján tartozik. (Ebben az esetben az érintett könyvtárat is értesíteni kell a kérésröl.)

i) A megadott adatok alapján nem tudtuk a kért dokumentumot azonosítani, pontosítást, további adatokat kérünk.

Amennyiben az a döntés születik, hogy a dokumentumot a könyvtár beszerzi, akkor annak beérkezése, feldolgozása és gyüjteményi helyre szállítása után kap az olvasó tájékoztatást a dokumentumhoz való hozzáférés lehetőségéről.

A feldolgozáskor a könyvtáros dönt a kérés során létrejött rekord és példány sorsáról. Ha talál a webOPAC-ban olyan rekordot, amely teljes, akkor a létrejött rekordot és a hozzá kapcsolódó példányt törli, és a meglévő rekordhoz kapcsolja az új példányt. Ha nem talál meglévő egyéb rekordot, akkor a kérés során létrejött rekordot és példányt egészíti ki. Lehetőség van a teljes rekord más adatbázisból való átemelésére, ekkor a kéréssel létrejött rekordot és példányt törölni kell.

\section{A szolgáltatás véglegesítése, statisztika}

A szolgáltatás véglegesítése, az egyes osztályok feladatának meghatározása folyamatban van. A feladatok felosztásánál elsődleges cél a hatékonyság kialakí- 
tása és a megfelelő külső és belső kommunikáció biztosítása. Feladattól függően szükséges lehet az Aleph katalogizáló és kölcsönző moduljainak betanítása, mivel a kérés során olvasói és példány oldalról is szükséges módosításokat, törléseket, kiegészítéseket végezni.

A szolgáltatás végleges kialakítása után készül el az ehhez kapcsolódó folyamatleírás mely tartalmazza többek között a folyamathoz szükséges erőforrásokat, a folyamatkategóriát, a vonatkozó szabályozást, a kritikus pontokat, a folyamat leírását, a keletkező és használandó dokumentumokat, a mérési és statisztikai pontokat. Ezt követően készül el a folyamatábra. A folyamat elfogadása és bevezetése után a szolgáltatás eszerint müködik. Idővel szükséges a folyamat felülvizsgálata, ha szükséges, akkor módosítása.

A szolgáltatásról statisztikai lekérdezés végezhető. A tervezett mérési periódus a havi lekérdezés. Ennek során mérjük a beérkezett kérések számát, a döntések milyenségét (beszerezzük, nem szerezzük be), a beszerzések számát, az átfutási időt (a kérés beérkezésétől a dokumentum hozzáférésének biztosításáig), a valamely ELTE-s könyvtárba továbbított kérések számát és azok teljesülését.

A statisztikáról a fenntartó és a karok könyvtárai is tájékoztatást kapnak.

\section{A szolgáltatás kommunikálása}

Az új szolgáltatásról olvasóinkat több formában is értesítjük. A könyvtárba beérkező olvasókat szóban tájékoztatjuk a szolgáltatásról, illetve szórólapot helyezünk el a könyvtár több pontján, az Információs pultnál és az olvasótermekben.

A portálon megjelentetjük a dezideráta szolgáltatás tájékoztatóját. Az olvasóknak küldött e-mailek végére a portálon megjelent hír linkjét bemásoljuk, és ideiglenesen beillesztjük a hamarosan lejáró kölcsönzésekről tájékoztató emlékeztető leveleink végére.

Az ELTE könyvtárosait az IKR hírlevélben és a Könyvtáros hírlevélben értesítjük, melyeket a Kolibri levelezőlistán keresztül küldünk ki.

\section{Rezümé}

A tanulmány a dezideráta szolgáltatás kialakításának folyamatát mutatja be. Kitér az Egyetemi Könyvtár szerzeményezésének és a dezideráta kérés leadásának jelenlegi, valamint új szemléletủ, jövőbeli gyakorlatára, érintve a hazai és a nemzetközi példákat is. Vázolja a fejlesztés során végzett változtatásokat mind az Aleph, mind a webOPAC rendszerre vonatkoztatva, részletezi az olvasói és példány oldalról a létrejött beállításokat. Bemutatja a kialakított dezideráta ürlapot és az olvasói tájékoztatás formáit. Szól a folyamat eddig kialakított lépéseiről olvasói és könyvtári oldalról. Kitér a kérésekhez kapcsolódó egyes esetekre. Részletezi a további feladatokat, a betanítást, a folyamatleírást, a szolgáltatás kommunikálását, valamint a tervezett statisztikai méréseket és az ehhez kapcsolódó fenntartói és könyvtáros tájékoztatást. 


\section{The Introduction of the Deziderata Service in the ELTE University Library}

The presentation shows the introduction process of the desiderata service. It covers the University Library's current practices of acquisition and of submitting desiderata requests as well as the new approaches and future practices, including national and foreign examples. It outlines the changes made in Aleph and in WebOPAC during the development, and details the settings created for both readers and documents. It presents the newly created desiderata application form, its fields and the ways of informing the readers. The presentation describes the steps already taken during the process for both readers and libraries. It presents some cases of requests and provides a template of letters to be sent out for readers. It also specifies additional tasks: taking trainings, working out process descriptions, communicating the service for both readers and librarians, as well as planning the collection of statistical data and providing guidance for librarians and university leaders.

CZINKI-VIETORISZ GABRIELLA informatikus könyvtáros ELTE Eötvös Loránd Tudományegyetem Egyetemi Könyvtár 